\title{
Identification of Groundwater Potential Zones in Khatav Tahsil using Geospatial Techniques
}

\author{
S.D. Shinde \\ Department of Geography, \\ Shivaji University, Kolhapur, \\ Maharashtra, India
}

\author{
V.B. Lingade \\ Department of Geography, \\ Shivaji University, Kolhapur, \\ Maharashtra, India
}

\author{
S.P. Aher \\ Department of Geography, \\ Shivaji University, Kolhapur, \\ Maharashtra, India
}

\begin{abstract}
The geospatial techniques like GIS, RS, cartography, spatial statistics etc. are used to well-organized planning of groundwater resources. In this study, base maps were prepared using digital image processing of RS data, digitization of existing maps in GIS for identification of Groundwater Potential Zones (GPZ). Four thematic layers, viz., geomorphology, drainage density, slope and lineaments were considered for identification of GPZ in the Khatav tahsil study area, Satara distract, Maharashtra. Administrative boundaries of sub circle belong to study area were superimposed over prepared thematic layers to know the circle wise outcome. Spatial data of thematic layers were assigned by ranks according to circle wise weights to their relative importance in groundwater occurrence. Final relative weight of four parameters (7-20) were used for identification of GPZ, like (1) high potential groundwater zone $(<11),(2)$ moderate potential groundwater zone $(11-18)$ and (3) low potential groundwater zone $(>18)$. Obtained results were also confirmed from dug well survey in the study area. The Vaduj and Katar Khatav circles ( $33.18 \%$ ) is falling in high potential groundwater zone and Pusegaon and Khatav circle (32.41\%) is belong with low potential groundwater zone.
\end{abstract}

\section{Keywords}

Geospatial techniques, Potential groundwater zone, Thematic layer, weighted rank.

\section{INTRODUCTION}

In the hydrological cycle groundwater is a distinguished component. It is to be found beneath the earth's surface in soil pore spaces, in the lineaments parallel to the stream courses and in the fractures of rock formations. Groundwater begins with rainfall, recharged from and eventually flows to the surface naturally. It is also often reserved for agricultural, municipal, industrial and domestic use. The amount of water that percolates into the ground is fluctuated spatially and temporally, depending on the gradient of surface, intensity of rainfall and lithology. Over half of the fresh water on earth is accumulated as groundwater. The improbability about the occurrence, distribution and quality aspect of the groundwater and energy requirement for its withdrawal impose restriction on exploitation ${ }^{1}$. Recently, water resources have been facing a variety of treats like declination of water quality due to discharge from polluted soils ${ }^{2}$ and by mixing of industrial effluents. Similarly, increasing demand to groundwater due to the inadequate availability of surface water resources ${ }^{3}$. Continues extraction of water by Borewell into ground is responsible for declining the groundwater level from last few decades. Thus, the precise identification of GPZ is a one of challenge in front of the earth scientist.
Identification of GPZ is resulted from combination of geophysical factors or parameters. The structural evolution of geological formation determined the geomorphology of an area and forms the topography along with drainage network systems. Most probably, geomorphological studies along with hydrology, geology, drainage density, surface slope etc. are conceded for exploration of GPZ. Similarly, lineaments parallel to the stream courses and intersecting-lineaments are favorable indicators for groundwater potential area ${ }^{4}$. Using convectional database extraction of impression of various parameters, like drainage network, glacier situation, water bodies, GPZ etc. are complicated, time consuming and giving uncertainty with ground reality ${ }^{5,6}$. Thus, the use of tools and techniques from geospatial environment will effective for identification of GPZ.

Geospatial techniques together with remote sensing (RS), geographic information system (GPS), global positioning system (GPS), cartography, geovisualization and spatial statistics are being used in various fields such as hydrology, forestry, environmental management, agriculture, health, homeland security etc. around the world. It is trustworthy technology for huge data handling and for database preparation with precise level ${ }^{7,8}$. Combine studies using conventional data, RS satellite data, its processing and interpretation in GIS environment is useful for the groundwater study ${ }^{9}$. Use of convectional data and its integration in geospatial technology is not only to increase the accuracy of results, but also to reduce the bias on any single theme ${ }^{3}$. The researchers ${ }^{10-}{ }^{16}$ have used the RS and GIS techniques in delineation studies of groundwater resources and its potential zones.

In view of this present attempt was carried out to identify the GPZ in the Khatav Tahsil study area using geospatial techniques. This area faces an acute problem of water for drinking irrigations and domestic purposes. The GPZ are unevenly distributed due to different topographical, hydrological and lithological background. Sufficient groundwater resource is reported to be existed in the study area which has not been properly exploited. Therefore, GPZ in need to identify properly for further groundwater exploration.

\section{THE STUDY AREA}

The study area is located in the Satara district of Maharashtra, India. The extent is from $17^{0} 22$ ' $48^{\prime \prime}$ to $17^{0} 53$ ' 24 " north latitude and from $74^{0} 13$ ' 12 " to $74^{0} 42$ ' $00^{\prime \prime}$ east longitude (Figure 1). The total area of present study area is 1377.79 sq. $\mathrm{km}$., comprising about 143 no. of villages and 2, 75,274 total populations according to census 2011. The maximum height is $1006 \mathrm{~m}$. observed in north-western part and minimum height is $572 \mathrm{~m}$. (MSL) observed in southern portion in the 
Yerala river bed. Maximum slope observed as 15 degree at the western margin while minimum is 0 degree in the southern portion of the study area. The middle segment of the study area is belonging to gentle slope with sediment deposition from the Yerala River and its tributaries. The western and northern part is consisted with structural and denudational hills which has composed of composite ridges and valleys traversed by structural features (Figure 2). The entire area is underlain by Deccan Trap basaltic lava flows of Upper Cretaceous to Lower Eocene age. The shallow alluvial formation of recent age also occurs as narrow stretch along the major rivers flowing in the area however, they have limited areal extension ${ }^{17}$.

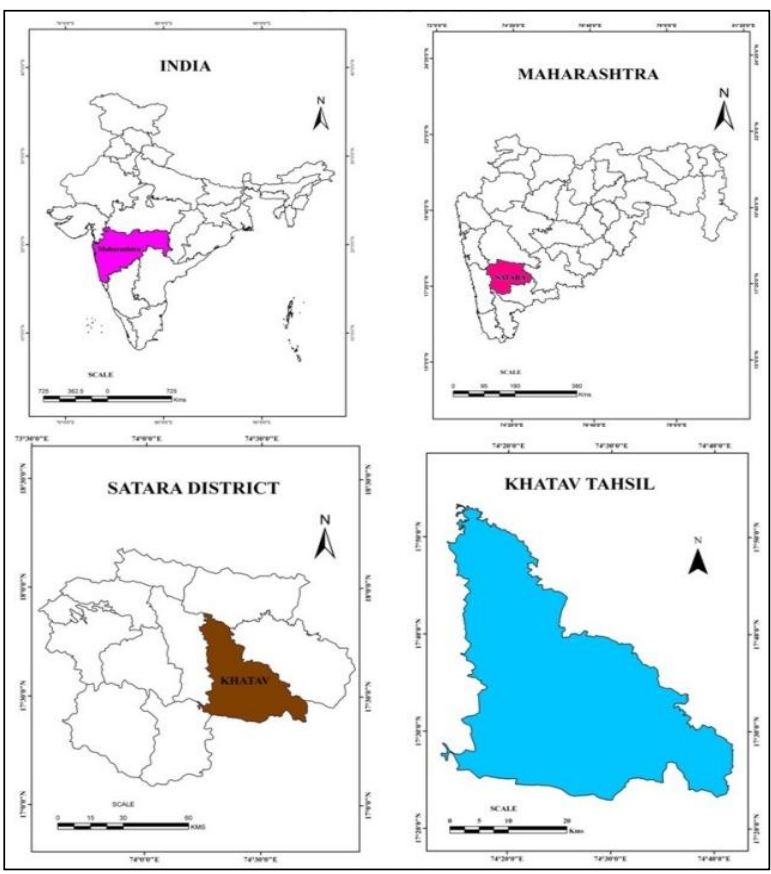

Figure 1. Location map of the study area

The drainage pattern located in the area characterized by different pattern and general flow tending toward south direction. In the western and north-eastern hilly region observed the high density of drainage along with greatest gradient (Figure 3 ). This zone is belonging to high runoff with little infiltration. The study area is located on the leeward slope of Western Ghat which is occupied by the rain shadow zone of Maharashtra. Somewhere, yearly average rainfall is measured less than $300 \mathrm{~mm}$. Therefore, in this area water problem become more severe in the summer due to lowering the groundwater level. Such characteristic are generate severe problem related to water availability for drinking and agricultural purpose, especially in every summer. The dominance of rainless crops, like Bajara, Kharif Jowar, Rabbi Jowar, Potato, Fruit farming and Pulses are also highlighting the drought oriented background of the area. In view of these characteristics and background of the study area, it was decided to identify the GPZ in the Khatav Tahsil using geospatial techniques.

\section{MATERIALS AND METHOD}

Base maps based on thematic layers were prepared using digital raster image processing of remote sensing data, digitization of existing maps in GIS environment and its validation by field check. Survey of India (SOI) topographic sheets $(47 / \mathrm{K}-5,47 / \mathrm{K}-6,47 / \mathrm{K}-7,47 / \mathrm{K}-8$, 47/K-9, 47/K-10,
47/K-11) on 1:50,000 scale, were scanned for digital data creation and preparation of relevant database. Topographical, administrative and pertinent maps of the study area are georeferanced using the projection UTM (Universal Traverse Mercator) and datum WGS84 (World Geodetic System 84). Administrative boundary and sub circles boundaries of the study area were extracted from political map of Maharashtra and groundwater surveys development agency (GSDA) hydrological report of Satara district respectively. To identify the GPZ in the study area parameters like, (1) geomorphology, (2) drainage density, (3) slope and (4) lineaments information were used in this attempt.

\subsection{Geomorphological Setting}

Hilly areas are belonging to high runoff with little infiltration due to composed of composite ridges and valleys traversed by structural features. Likewise, in hilly area residual hill $(\mathrm{RH})$ is a deprived geomorphological unit in respect to GPZ. However, adequate recharge source of groundwater can be expected surrounding the $\mathrm{RH}$, as it acts as surface runoff zone $^{4}$. In a different way, plain or moderately buried plain is shallow depressed low relief area with good drainage networks, where observed moderate infiltration and good recharge by hydrological process ${ }^{18,19}$. The geomorphological map of the study area was prepared from CartoDEM (V3R1), downloaded from NRSC, Bhuvan site, reference - E43O. This data was processed in ArcGIS software with spatial analyst module. Topographic sections based on elevation were prepared, like (1) hilly area (> $900 \mathrm{~m}$.), (2) foot hills area (600 to $900 \mathrm{~m}$.), and (3) plain area $(<600 \mathrm{~m}$.) (Figure 2).

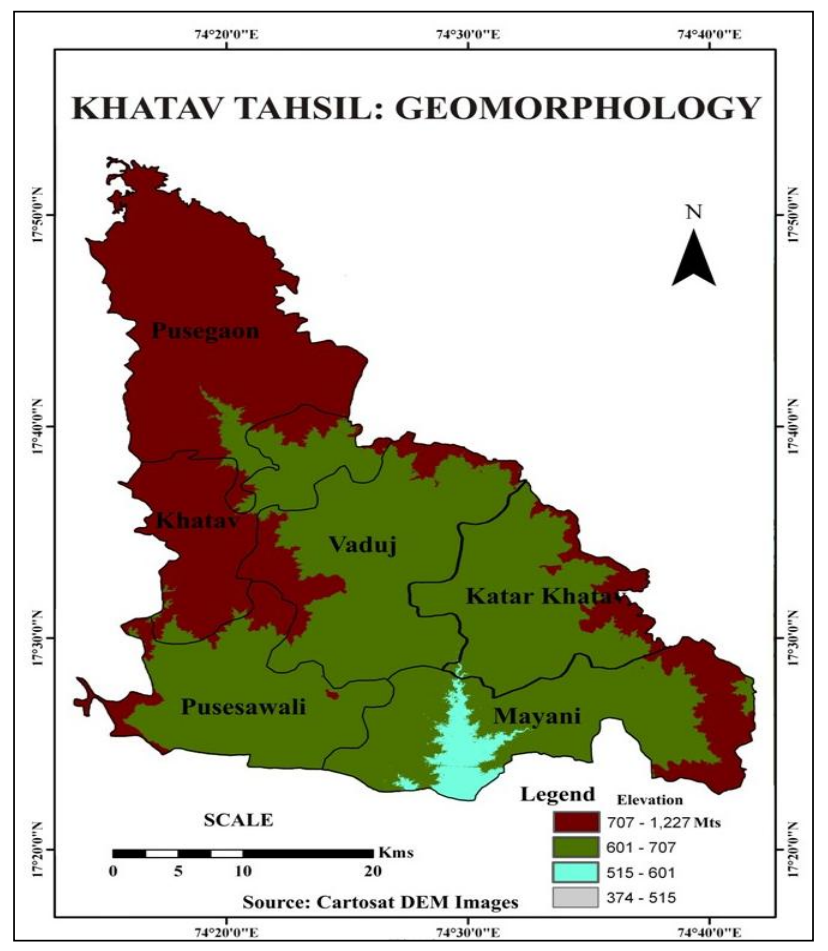

Figure 2. Topographical section of the study area

Administrative boundaries of six circles namely, the Pusegaon, Khatav, Pusesawali, Vaduj, Katar Khatav and Mayani were superimposed over three topographic sections map. Circle wise topographic analysis were carried out and ranked the total weightage of each circle according to its relative weight (Table 1). 
Table 1. Circle wise geomorphological analysis of the study area

\begin{tabular}{|c|l|c|c|c|c|c|}
\hline Sr. No. & Circle & Hilly Area $(\boldsymbol{\%})$ & Foot Hills (\%) & Plain Area (\%) & Total (\%) & Rank \\
\hline 1 & Pusegaon & 95.73 & 4.27 & 0.00 & 100.00 & 6 \\
\hline 2 & Khatav & 69.11 & 30.89 & 0.00 & 100.00 & 5 \\
\hline 3 & Pusesawali & 15.06 & 84.94 & 0.00 & 100.00 & 2 \\
\hline 4 & Vaduj & 16.37 & 83.63 & 0.00 & 100.00 & 4 \\
\hline 5 & Katar Khatav & 15.18 & 84.82 & 0.00 & 100.00 & 3 \\
\hline 6 & Mayani & 18.81 & 68.43 & 12.76 & 100.00 & 1 \\
\hline
\end{tabular}

\subsection{Drainage Density Calculation}

The drainage density is an inverse function of permeability. It is defined as the proximity of spacing of stream channels which is measure as total length of stream segment of all orders per unit area. The less permeable a rock is, the less the infiltration of rainfall, which conversely tends to be concentrated in surface runoff ${ }^{20-22}$. In this study, the drainage density may be indirectly specifying the groundwater potential of an area due to its relation to surface runoff and permeability. Hence, it was considered as one of the indicators for GPZ occurrence in the present study area. The drainage networks/pattern along with major Yerala, Nani and Chand rivers of the study area were extracted from topographical sheets by manual digitization in ArcGIS 9.3 platform. Administrative boundaries of six circles were superimposed over drainage network map to identify the circle wise drainage density in the study area (Figure 3 ).

After extraction of drainage network from entire study area circle wise drainage density was calculated by using formula.

Drainage Density $=$ Total length of stream / Total area of basin

After the calculation of circle wise drainage density relative rank to each circle were assigned according to obtained weight (Table 2).

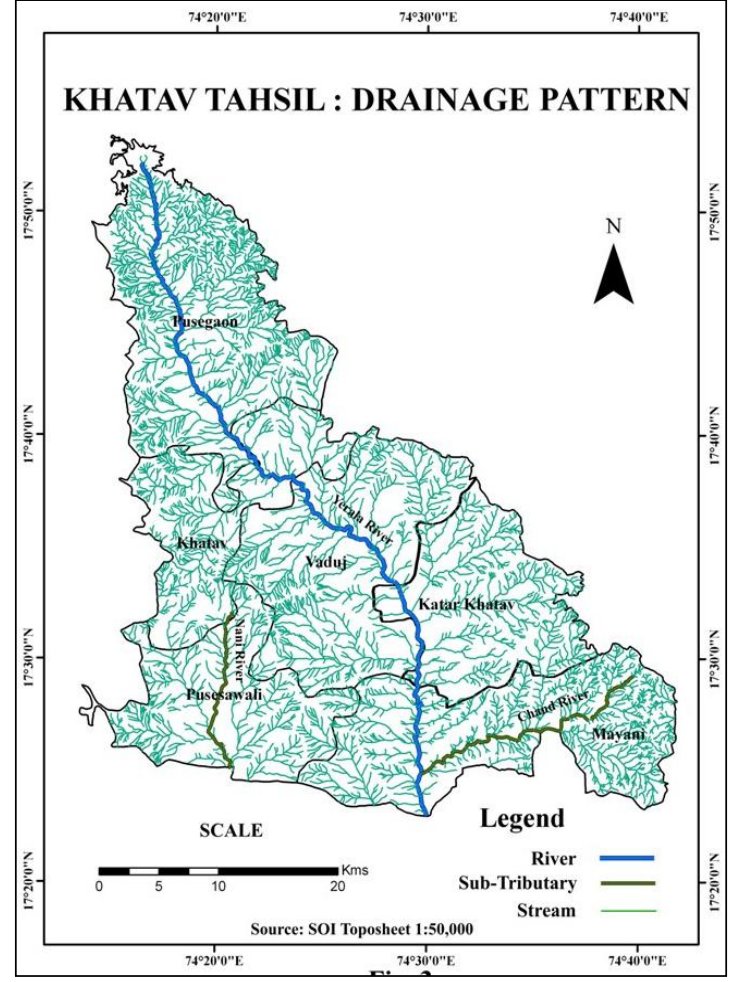

Figure 3. Drainage network of the study area

Table 2. Circle wise Drainage Density of the Study Area

\begin{tabular}{|c|c|c|c|c|c|c|}
\hline No. & Circle & Area $\left(\mathbf{K m}^{2}\right)$ & No. of Streams & Length $(\mathbf{K m})$ & Drainage Density $\left(\mathbf{k m} / \mathbf{k m}^{2}\right)$ & Rank \\
\hline 1 & Pusegaon & 298.99 & 1425 & 746.19 & 2.50 & 6 \\
\hline 2 & Khatav & 163.52 & 526 & 318.87 & 1.95 & 4 \\
\hline 3 & Vaduj & 259.62 & 648 & 491.72 & 1.88 & 1 \\
\hline 4 & Katar Khatav & 186.51 & 557 & 351.85 & 1.93 & 2 \\
\hline 5 & Pusesawali & 179.13 & 526 & 345.56 & 2.34 & 3 \\
\hline 6 & Mayani & 256.73 & 1273 & 600.36 & & 5 \\
\hline
\end{tabular}

\subsection{Slope Derivation}

Slope is an important aspect for the identification of GPZ. The process of surface runoff depends on slope which also impact on the percolation process. Magesh et al., (2011), stated that, higher degree of slope results in rapid runoff and increased erosion rate with feeble recharge potential. According to Burrough $^{23}$, (1986), slope grid in digital raster data is identified as the maximum rate of change in value from each cell to its neighbors. Slope map of the study area were prepared from CartoDEM (V3) data using spatial analysis tool in ArcInfo 9.3 (Figure 3).

Based on derived slope map entire study area was divided into four main classes of slope. Circle wise slope area was calculated and assigned the relative rank to each circle according to obtained weight of the slope (Table 3 ). 


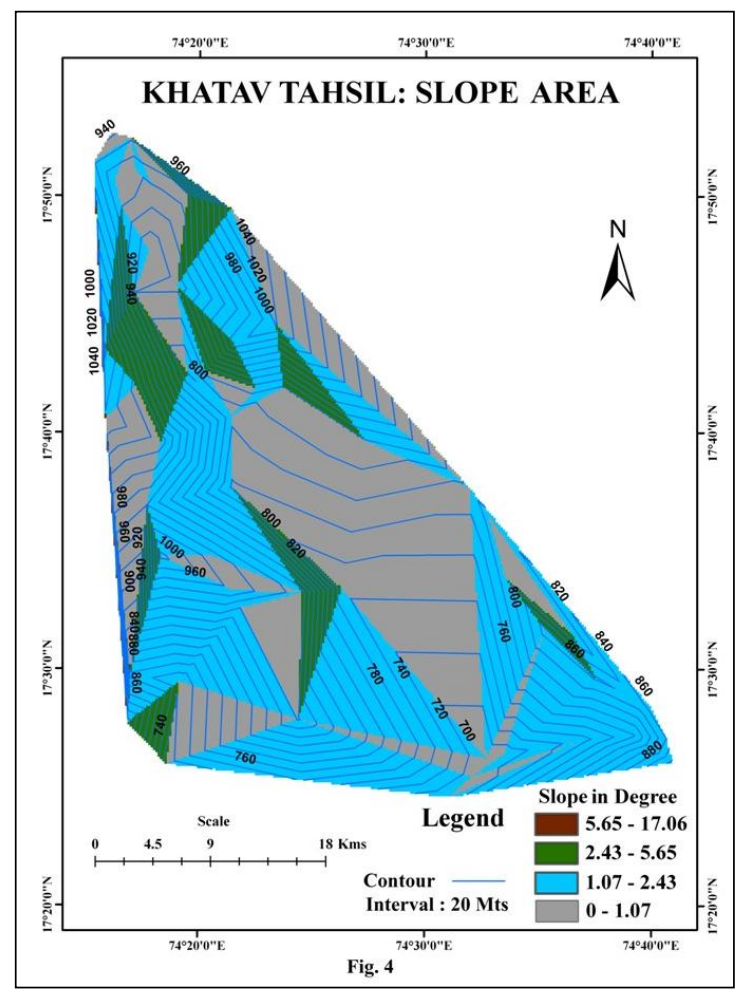

Figure 4. Slope map of the study area

\subsection{Lineament Mapping}

Lineaments represent the zones of faulting and fracturing resulting in increased secondary porosity and permeability which provide the path ways for groundwater flow. Lineament density of an area can indirectly reveal the groundwater probable and areas with high lineament density are providing the impression of GPZ ${ }^{24}$. Lineaments can be identified directly on the rock units or from RS data which play a significant role in the occurrence and movement of groundwater in crystalline rocks ${ }^{4,25,26}$. Lineament map for the present study area was prepared from GSDA hydrological report of Satara district and also verified from CartoDEM data (Figure 5).

Later then, the circle wise lineaments length were calculated and allotted the relative rank according to total length weight of the lineaments in particular circle (Table 4).
Table 4. Circle wise lineament length in the study area

\begin{tabular}{|c|c|c|c|}
\hline S. No. & Circle & Length $(\mathbf{K m})$ & Rank \\
\hline 1 & Pusegaon & 21.27 & 5 \\
\hline 2 & Khatav & 12.39 & 6 \\
\hline 3 & Vaduj & 35.39 & 1 \\
\hline 4 & Katar Khatav & 31.85 & 4 \\
\hline 5 & Mayani & 32.54 & 3 \\
\hline 6 & Pusesawali & 34.11 & 2 \\
\hline
\end{tabular}

\subsection{Identification of GPZ}

Hydrogeomorphological investigations comprise the demarcation and mapping of various landforms, drainage characteristics and structural features that could have a direct control on the occurrence and flow of groundwater 27,28 . Integration of base maps viz. geomorphologic, drainage density, slope, lineaments etc. were carried out for the detection of GPZ. Assigned relative ranks were integrated with respect to circle and selected parameters. Delineated circles total weight was calculated from relative ranks addition (Table 5).

Table 5. Circle wise weight of all parameters

\begin{tabular}{|l|c|c|c|c|c|}
\hline Circle & Geomo. & Drain. & Slope & Lin. & Sum \\
\hline Pusegaon & 6 & 6 & 3 & 5 & 20 \\
\hline Khatav & 5 & 4 & 4 & 6 & 19 \\
\hline Vaduj & 4 & 1 & 1 & 1 & 7 \\
\hline Katar Kh. & 3 & 2 & 2 & 4 & 11 \\
\hline Mayani & 1 & 5 & 6 & 3 & 15 \\
\hline Pusesawali & 2 & 3 & 5 & 2 & 12 \\
\hline
\end{tabular}

From these circle wise weight, three Groundwater Potential Zones like, (HPGZ) high potential groundwater zone $(<11)$, (MPGZ) moderate potential groundwater zone $(11-18)$ and (LPGZ) low potential groundwater zone (> 18) were indentified in the study area. Final circle wise GPZ map of the study area were prepared after the calibration of results in the study area by survey of dug well water level checking (Figure $6)$.

Table 3. Circle wise slope analysis of the Khatav Tahsil

\begin{tabular}{|c|c|c|c|c|c|c|c|}
\hline No. & Circle & $5.65^{0}-17.06^{0}$ & $2.43^{0}-5.65^{0}$ & $1.07^{0}-2.43^{0}$ & $0^{0}-1.07^{0}$ & Total & Rank \\
\hline 1 & Pusegaon & 12.48 & 86.12 & 118.54 & 74.43 & & \\
\hline 2 & Khatav & 6.52 & 9.78 & 76.78 & 73.21 & 166.29 & 4 \\
\hline 3 & Vaduj & 00 & 29.51 & 38.81 & 112.2 & 180.52 & 1 \\
\hline 4 & Katar Khatav & 00 & 8.01 & 70.34 & 89.53 & 167.88 & 2 \\
\hline 5 & Mayani & 00 & 00 & 142.29 & 27.2 & 169.49 & 6 \\
\hline 6 & Pusesawali & 6.91 & 11.8 & 87.62 & 29.05 & 135.38 & 5 \\
\hline
\end{tabular}




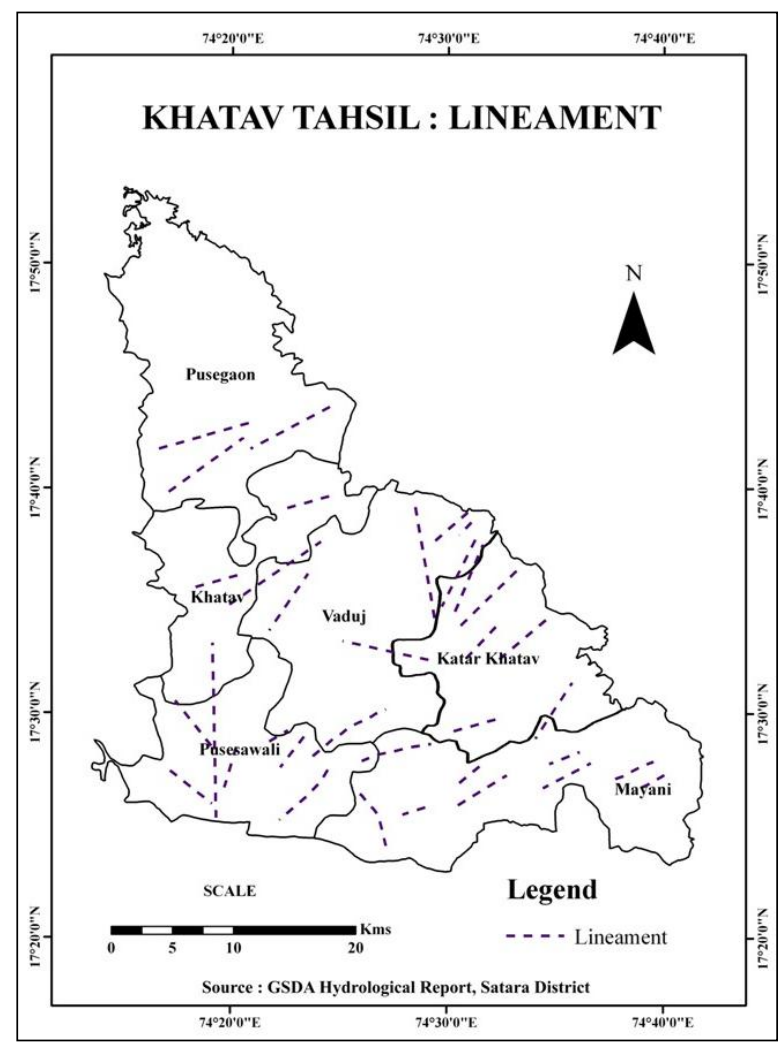

Figure 5. Lineament map of the study area

\section{RESULTS AND DISCUSSION}

\subsection{Geomorphologic Background}

The geographical location of the study area consisted with marginal boundary of Deccan upland, a part of Western Ghat. According to geomorphologic analysis, about $45 \%$ area confined by the plain area, $34 \%$ by foot hills and below $20 \%$ area covered by hilly ranges (Figure 2). In the Mayani circle $12.76 \%$ area consisted with plain topography which is main region for HGPZ in the study area. From the exposed three types of geomorphic units (hill ranges - > 900 m., foot hills 600 to $900 \mathrm{~m}$., plain area $-<600 \mathrm{~m}$.) hilly area is the not conform to GPZ due to structural and denudational hills with composite ridges and valleys traversed by structural features. Therefore, these zones are belonging to high runoff with little infiltration. The dominant hilly area is consisted with Pusegaon circle (95.73\%) which is the LGPZ area. These acquired results were also confirmed by field verification in the study area.

\subsection{Drainage Density}

Maximum calculated drainage densities were found in the Pusegaon circle $(2.50 \mathrm{~km} / \mathrm{sq} . \mathrm{km})$ due to elevated structural hills (Table 2). However, maximum gradient in the study area is responsible to high runoff with little infiltration in rainy seasons. Means, greater the drainage density, higher would be runoff. Similar characteristic were also noticed in the Khatav circle. Therefore, the Pusegaon and Khatav circles are under the LGPZ (Figure 6). In the surrounding region of the Yerala, Nani and Chand rivers observed better groundwater levels due to infiltration capacity of deposited sediments in there sections. In the study area, most of the drainage originates from the hills in the north-western part of the tahsil showing variation in the density (Figure 3). This is the result of elevated and undulating topography at both the east-west edges of the study area. Least drainage density is distributed in Vaduj circle $(1.88 \mathrm{~km} / \mathrm{sq} . \mathrm{km})$. Similar characteristic were also noticed in the Katar Khatav $(1.89 \mathrm{~km} / \mathrm{sq} . \mathrm{km})$ circle. Therefore, both the circles are in the HGPZ in the study area (Figure 6).

\subsection{Slope Situation}

In the present study area, topographic slope is affecting the runoff, recharge and movement of surface water. It is because of slope gradient directly influences the infiltration of rainfall. In the gentle slope area, the surface runoff is slow allowing more time for rainwater to percolate, whereas high slope area facilitate high runoff allowing less residence time for rainwater hence comparatively less infiltration. In this study, about $58 \%$ of the study area was classified as nearly level to very gentle slope in the tahsil. Also, the $25.91 \mathrm{Sq}$. Km. covered by the high degree slope. The dominant gentle slope is found in the Vaduj circle are occupied nearly 112.2 sq.km area. The least gentle slope is distributed in Mayani circle is around 27.2 sq. km. (Table 3). The part of the Vaduj, Katar Khatav and Mayani circles are not consisted with hilly topography. Maximum southern part of the study area is belonging with the Yerala, Nani and Chand rivers catchments with minimum slopes. Therefore, the HGPZ located in the plain topography of the study area like, the Vaduj and Katar Khatav circles (Figure 6).

\subsection{Lineament Setting}

The lineaments in the study area were observed with maximum length in the Vaduj circle $(35.39 \mathrm{~km}$.) which playing a significant role in the occurrence and movement of groundwater with respect to lithology, slopes and proximity of streams networks. In the entire study area above 30 lineaments were observed which has nearly $167.55 \mathrm{~km}$. lengths. Numerous lineaments have been extracted and mapped which is shown in Table 4 and figure 5, trending northeast to southwest, north to south and northwest to southeast directions. The dominant lineament length is indicated in the Vaduj circle ( $35.39 \mathrm{Km}$.) which is also HGPZ in the study area. Whereas, the least length of lineament have been found in the Khatav circle $(12.85 \mathrm{Km})$, which is LGPZ in the study area.

\subsection{Identification of GPZ}

The HGPZ are observed in the Vaduj and Katar Khatav circle due to most of the parts of these circles is covered by the Yerala river basin (Figure 3 and 6). Several characteristic could be explained as reasons for HGPZ in these regions, (1) below $17 \%$ area confirm as a under the hilly area, (2) nearly $1.90 \mathrm{~km} / \mathrm{sq} . \mathrm{km}$ drainage density, (3) above $60 \%$ area comes under less than 1.07 degree slope and (4) More than $20 \%$ length of lineament is measured (Table 6).

Similarly, in the Mayani and Pusesawali circles were observed the MGPZs (Figure 6). These areas are belonging to slightly plain topography which interference along with hilly area somewhere. There are number of reasons behind of MGPZ in these regions, these are: (1) nearly, $18 \%$ area confines under the hilly area, (2) about $2.00 \mathrm{~km} / \mathrm{sq} . \mathrm{km}$ drainage density, (3) below $30 \%$ area comes under less than 1.07 degree slope and (4) less than $20 \%$ lineament in these circles (Table 6).

The Pusegaon and Khatav circles are belong to LGPZ (Figure 6 ). It is because of the majority of part of these areas is 
consisted with structural and denudational hills with composite ridges and valleys. Therefore, these zones are belonging to high runoff with little infiltration. Further some characteristic are belong with these circles: (1) above $60 \%$ area confines under the hilly area, (2) more than 2.00 $\mathrm{km} / \mathrm{sq} . \mathrm{km}$ drainage density, (3) below $15 \%$ area comes under less than 1.07 degree slope and (4) nearly $10 \%$ length of lineament in the study area (Table 6).

Table 6. Delineation criterion for GPZ identification

\begin{tabular}{|c|l|c|c|c|}
\hline \multirow{2}{*}{ GPZ } & $\begin{array}{l}\text { Groundwater } \\
\text { Potential }\end{array}$ & HPGZ & MPGZ & LPGZ \\
\cline { 2 - 5 } & $\begin{array}{l}\text { Delineation } \\
\text { Criteria }\end{array}$ & $<\mathbf{1 1}$ & $\begin{array}{c}\mathbf{( 1 1}- \\
\mathbf{1 8})\end{array}$ & $>\mathbf{1 8}$ \\
\hline 1 & Hilly Area (\%) & $<17$ & 18 & $>60$ \\
\hline 2 & $\begin{array}{l}\text { Drainage Den. } \\
\text { (Km/sq.km) }\end{array}$ & 1.90 & 2 & $>2$ \\
\hline 3 & Slope Area (\%) & $>60$ & $>30$ & $<15$ \\
\hline 4 & Lineament (\%) & $>20$ & $<20$ & 10 \\
\hline
\end{tabular}

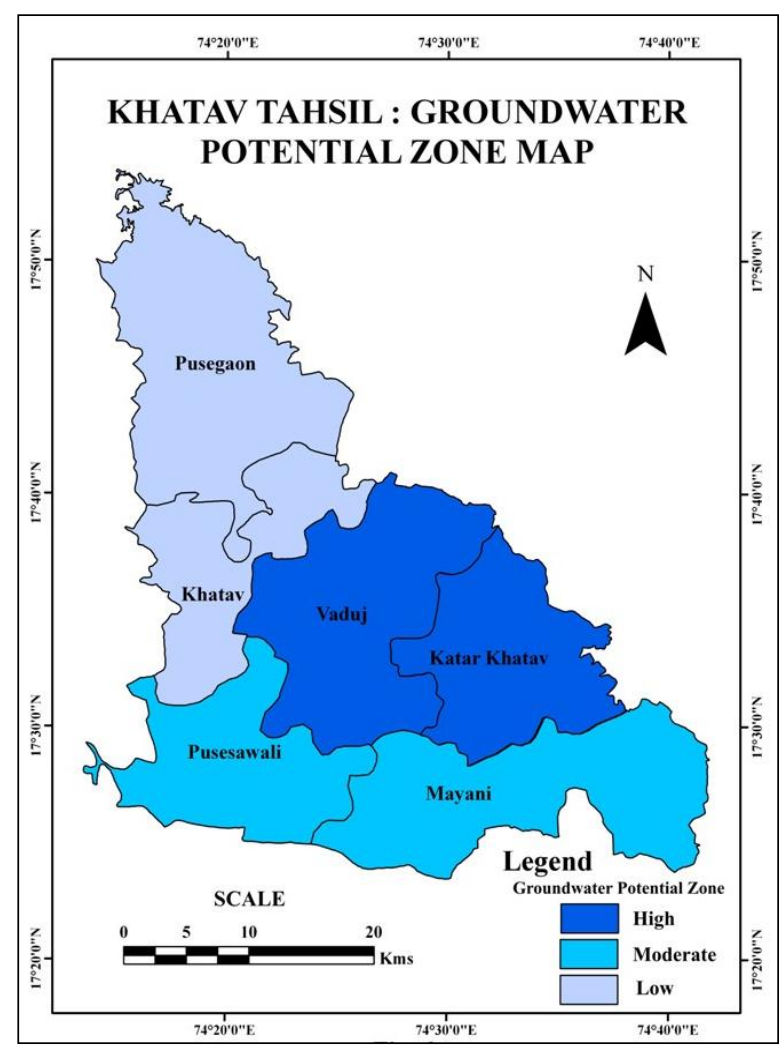

Figure 6. Groundwater Potential Zones in the study area

\section{SUMMERY AND CONCLUSION}

The tools and techniques used in this attempt from geospatial environment with data capturing, storing, manipulation and computing for GPZ identification in the study area. Prepared base maps from digital raster image, topographical maps and relevant database in GIS environment is more precise and thematic base oriented. According to reveled results, the Pusegaon and Khatav circles are belong to LGPZ in the entire study area where need of water conservation practices implementation for enhancing the GPZ. After that, in the Mayani and Pusesawali circles also need a few water conservation practices. Nearby, $32.41 \%$ of area is consisted with LGPZ in the present study area. These obtained results in GIS environment were also confirmed from dug well survey during various seasons in the study area by field check. Therefore, reveled results and adopted methodology are most suitable for rapid assessment of GPZ and its identification. As a conclusion geospatial technology can be used for wellorganized planning of imperative groundwater resources after identification of Groundwater Potential Zones in the various environmental regions.

\section{ACKNOWLEDGEMENT}

The authors are thankful to Department of Geography, Shivaji University, Kolhapur (MS), for support and providing necessary research facilities. Praveen B. Gawali (Indian Institute of Geomagnetism, Mumbai) and Barbara TheilenWillige (Institute of Applied Geosciences, Germany) are thanked for intellectual discussions and timely support.

\section{REFERENCES}

[1] Pandey, N. K., Shukla, A. K., Shukla, S. \& Pandey, M. 2014. Assessment of Underground Water Potential Zones Using Modern Geomatics Technologies in Jhansi District, UP. Int. Archives of the Photogrammetry, Remote Sen. and Spatial Inf. Sci., XL-8, 377-381.

[2] Deshmukh, K. \& Aher, S. 2014. Particle Size Analysis of Soils and Its Interpolation using GIS Technique from Sangamner Area, MS, India. Int. Res. J. of Env. Sci.3 (10), 32-37.

[3] Rao, Y. \& Jugran, D. 2003. Delineation of Groundwater Potential Zones And Zones of Groundwater Quality Suitable For Domestic Purposes Using Remote Sensing and GIS. Hydrological Sciences Journal, 48 (5), 821-833.

[4] Rao, N. S., Chakradhar, G. K. J. \& Srinivas, V. 2001. Identification of Groundwater Potential Zones Using Remote Sensing Techniques In and Around Guntur Town, Andhra Pradesh, India. J. of the Indian Society of Remote Sensing, 29, (1-2), 69-78.

[5] Aher, S. and Dalvi, S. 2012. Remote Sensing Technique for Monitoring the Glacier Retreating Process and Climatic Changes Study. Indian Streams Research J., 2 (8), 2-6.

[6] Deshmukh, P., Wawale, S., Aher, S. \& Thorat, S. 2012. Demarcation of Drainage Network For Watershed Management of Sangamner Tahsil using Topographical and Remote Sensing Database. Indian Stream Research J., 2 (1), 1-4.

[7] Aher, S., Parande, A., \& Deshmukh, P. 2011. A Geomatics of the Image Processing: Image Georeferancing. Proceedings published in Int. J. of Computer Applications, 20-23.

[8] Thakur, J. K., Singh, S. K., Ramanathan, A., Prasad, B.K.M., \& Gossel, W. (Eds.) 2012. Geospatial Techniques for Managing Environmental Resources, Springer Book Archives.

[9] Aher, S. P., Shinde S. D. and Kemnar S. 2014. Synthetic Aperture Radar in Indian Remote Sensing. Int. J. of Applied Information System, 2 (7), 41-44.

[10] Saraf, A. \& Jain, S. 1994. Integrated use of remote sensing and geographical information system methods for groundwater exploration in parts of Lalitpur district, UP. Int. Conf. on Hydrology and Water Resources, New Delhi, Kluwer Academic Publishers, Netherlands. 
[11] Kamaraju, M. V. V., Bhattacharya, A., Srinivasa Reddy, G., Chandrasekhar Rao, G., Murthy, G. S. \& Malleswara Rao, T.C. H. 1996. Groundwater potential evaluation of west Godavari district, A.P., India -a GIS approach. Groundwater 34 (2), 318-325.

[12] Ravindran, K. V. 1997 Drainage morphometry analysis and its correlation with geology, geomorphology and groundwater prospects in Zuvari basin, South Goausing RS \& GIS. Proc. Nat. Symp. Remote Sensing for Natural Resources with Special Emphasis on Water Management, (Pune, India, 4-6 December 1996), 270296.

[13] Pradeep, K. J. 1998. Remote Sensing techniques to locate groundwater potential zones in upper Urmil river basin, District Chatarpur, Central India. J. Indian Soc. Remote Sensing, 26 (3), 135-147.

[14] Ashok K. 1999. Sustainable utilization of water resources in watershed perspective - a case study in Alaunja watershed, Hazaribagh, Bihar. J. Indian Soc. Remote Sensing 27(1), 13-22.

[15] Khan, M. A. \& Moharana, P. C. 2002. Use of remote sensing and GIS in the delineation and characterization of groundwater prospect zones. J. Indian Soc. Remote Sen., 30 (3), 131-141.

[16] Rokade, V. M., Kundal, P, \& Joshi A.K. 2007. Groundwater potential modeling through Remote Sensing and GIS: A case study from Rajura Taluka, Chandrapur District, Maharashtra. J. Geol. Soc. India, 69, 943-948.

[17] GSDA, 2009. Groundwater survey development agency. Hydrological report of Satara district.

[18] Mayilvaganan, M. K., Mohana, P. \& Naidu, K. B. 2011. Delineating groundwater potential zones in Thurinjapuram watershed using geospatial techniques. Indian Journal of Science and Technology, 4 (11), 14701476.

[19] Deshmukh, K. \& Aher, S. 2015. Impact of land-use changes on groundwater quality from Sangamner area,
Ahmednagar district, Maharashtra, India. Proceeding of ICPAC-2014-2015 (In Press).

[20] Basavaraj, H. \& Nijagunappa, R. 2011. Identification of Groundwater Potential Zone using Geoinformatics in Ghataprabha basin, North Karnataka, India. Int. J. of Geomatics and Geosciences, 2(1), 91-109.

[21] Magesh, N. S., Chandrasekar, N. \& Soundranayagam, J. P. 2012. Delineation of groundwater potential zones in Theni district, Tamil Nadu, using remote sensing, GIS and MIF techniques. Geoscience Frontiers, 3 (2), 189196.

[22] Aher, S. P., Bairagi, S. I., Deshmukh, P. P. \& Gaikwad, R. D. 2012. River change detection and bank erosion identification using topographical and remote sensing data. Int. J. of Appl. Information System, 2, 1-7.

[23] Burrough, P.A. 1986. Principles of Geographical Information Systems for Land Resources Assessment. Oxford University Press, New York, 50.

[24] Haridas, V. R, Aravindan, S. \& Girish, G. 1998. Remote sensing and its applications for groundwater favorable area identification. Quarterly Journal of GARC, 6, 1822.

[25] Prasad, R.K., Mondal, N.C., Banerjee, P., Nandakumar, M.V. \& Singh, V.S., 2008. Deciphering potential groundwater zone in hard rock through the application of GIS. Environmental Geology, 55, 467- 475.

[26] Aher, S. P., Shinde, S. D., Jarag, A. P. \& Gawali, P. B 2014. Identification of Lineaments in the Pravara Basin from ASTER-DEM Data and Satellite Images for their Geotectonic Implication. Int. J. of Earth Sciences, 2 (7), $1-5$.

[27] NRSA 2000. Rajiv Gandhi National Drinking Water Mission: Technical Guidelines for Preparation of Groundwater Prospects Maps, National Remote Sensing Agency, Department of Space, Hyderabad, India.

[28] Soman, K. 2002. Geology of Kerala. Geological Society of India, Bangalore, 34-39. 